\title{
СИНТЕЗ И NНЕ-1-ИНГИБИРУЮЩАЯ АКТИВНОСТЬ НОВЫХ ПРОИЗВОДНЫХ ХИНАЗОЛИН-2,4(1Н,3Н)-ДИОНА
}

\author{
Н.В. Овсянкина, Д.В. Мережкина, Г.С. Лызо
}

Волгоградский Государственный Медицинский Университет Минздрава РФ, 400131, Россия, г. Волгоград, пл. Павших Борцов, 1

DOI: 10.19163/MedChemRussia2021-2021-335

E-mail: ovsyankina99@mail.ru

Перспективным направлением цитопротекции является поиск и изучение ингибиторов NHE-1 - обменника, активно представленного в клетках крови, миокарде и тканях мозга. Производные гуанидина и хиназолина обладают широким спектром биологической активности, поэтому представляют интерес для создания на их основе методами медицинской химии комбинаторных библиотек новых молекул.

Взаимодействие сложноэфирных производных хиназолин-2,4(1Н,3H)диона с гуанидина гидрохлоридом и аминогуанидина карбонатом в спиртовой среде в присутствии едкого кали приводит к новым гуанидиновым и аминогуанидиновым производным хиназолин-2,4(1Н,3Н)-диона, при этом последние способны циклизоваться при повышенной температуре с образованием триазолильных фрагментов в составе боковой цепи $\mathrm{R}^{1}$ и $\mathrm{R}^{2}$ :<smiles>[R]c1ccc2c(c1)c(=O)n([R])c(=O)n2[R]</smiles>

где: $\mathrm{R}^{1}, \mathrm{R}^{2}=\mathrm{CH}_{3}, \mathrm{CH}_{2}-\mathrm{CH}=\mathrm{CH}_{2}, \mathrm{CH}_{2}-\mathrm{Ph}, \mathrm{CH}_{2}-\mathrm{C}(\mathrm{O})-\mathrm{O}-\mathrm{CH}_{2}-\mathrm{Ph}, \mathrm{CH}_{2}-\mathrm{C}(\mathrm{O})-\mathrm{NH}-\mathrm{C}(\mathrm{NH})-\mathrm{NH}_{2}$,

$\mathrm{CH}_{2}-\mathrm{C}(\mathrm{O})-\mathrm{NH}-\mathrm{C}(\mathrm{NH})-\mathrm{NH}_{2}-\mathrm{NH}_{2}, \mathrm{CH}_{2}$-(5-амино-1 H-1,2,4-триазол-3-ил)

$\mathrm{R}^{3}=\mathrm{H}, \mathrm{Br}$

В исследованиях in vitro на тромбоцитах кролика по методу Rosskopf (1991) и Kusumoto (2002) изучена NHE-1-ингибирующая активность новых производных хиназолин-2,4(1H,3Н)-диона в концентрации $1 \times 10^{-8}$ М в сравнении с римепоридом, известным ингибитором данного обменника. Показано, что наиболее выраженную активность, подобную препарату сравнения, проявляют соединения с триазолильными фрагментами в составе боковой цепи $\mathrm{R}^{1}$ и $\mathrm{R}^{2}$.

Синтез и изучение биологической активности новых производных хиназолин-

2,4(1Н,3Н)-диона выполнены за счет Соглашения № 075-15-2020-777 от «1» октября 2020 г. о предоставлении из федерального бюджета грантов в форме субсидий в соответствии с пунктом 4 статьи 78.1 Бюджетного кодекса Российской Федерации, г. Москва. 